\title{
PATRICK HENRY AND ST. GEORGE TUCKER.
}

I have in my possession three manuscript volumes, bound in sheep, entitled, "Notes of Cases." On the first page of the first volume in the handwriting of St. George Tucker is the following:

\section{"NOTES}

of certain decisions in the General Court, District Courts, and Court of Appeals in Virginia, from the year 1776 to $181 \mathrm{I}$... the whole in three volumes preserved for my own use, and that of my own family-S. G. Tucker."

On the fly leaf of the first volume is written the following: "Bequeathed by the late William Green to his brother, James W. Green and by him presented to the Honorable J. Randolph Tucker, October 2I, 1880."

The notes give the style of the case, the pleadings therein, often the names of counsel, the points of argument of counsel on the pleadings, and opinion of the judge. The whole manuscript is perfectly written in a legible flowing hand. The handwriting is that of Judge Tucker. Examining these volumes I found on page 60 of the first volume this curious memorandum inserted in between the notes upon two different cases: "Memo, the late Gov. Henry came into court to acknowledge a Deed; he stood some moments near the Bar, but was not asked by the court to come upon the Bench. Oct. 17, 1787. Ex relatione Lee." When my eye fell upon this memorandum in the examination of these notes, I read it again and again, and was at a loss to know what it meant. My first thought was of that much moot-question, who, if any, should be asked through courtesy to sit with the court, and that it was intended to show that the rule of the Virginia courts was against asking distinguished personages to sit with the judges on the bench. The custom of the courts throughout the United States on this question is quite different in different places. The Supreme Court of the United States, if I remember rightly, has asked the Lord Chief Justice 
of England to sit with them when he visited that Court. The Supreme Courts of the several States have in some instances invited distinguished lawyers and statesmen to sit with them during the hearing of cases when visiting the courts. While the rule of the Nisi Prius Courts, State and Federal, is broader and embraces a larger number of persons who are deemed worthy of such attention. My thought at first was, therefore, that the memorandum was made for the purpose of showing what the custom of the Virginia Court was, but the more I read it the more I was impressed with the emphasis which seemed to inhere in the phrase, "but was not asked by the court to come upon the Bench." The word "but" seemed to me to be the key of the explanation, and still the wonder grew why in the serious work of disposing of cases the judge should have deemed it necessary to stop in the midst of his work to record this passing incident. My final conclusion, after thinking it over for weeks and several months, was that it showed there had been some personal feeling between Judge Tucker and Governor Henry, though I had never heard of anything of the kind. A few months after my discovery, at the meeting of the Virginia Bar Association at the Hot Springs, Virginia, I met Patrick Henry's grandson, that noble gentleman and distinguished lawyer, the late William Wirt Henry, of the Richmond Bar. Without telling him what I had found, and with no explanation, I said to him, "Mr. Henry, did your grandfather, Patrick Henry, and my great-grandfather, St. George Tucker, ever quarrel?" With a suggestive smile on his face he replied, "Harry, the first time you are in Richmond come to my office and I will show you something of interest." We passed on and this was the whole conversation. I did not get to Richmond at any time in the near future, and in a few months death had claimed Mr. Henry. By his death the mystery was still unsolved.

Some years after this event I was down in Buckingham County in a political campaign, and after speaking at the Court House I met the Honorable James Lyons, that courtly gentleman of the old school, who had married Mr. Henry's daughter, whom I had known from youth. They were living at that time near. 
Buckingham Court House, and Mr. Lyons asked me to go and spend the night with him, and I accepted. After supper that evening I told his wife of the conversation between her father and me at the Hot Springs, and I asked her if she could make any explanation of it. She said at once, "I have a large bundle of letters upstairs from your great-grandfather, St. George Tucker." I said to her, "Do go up and bring one of them down and let me look at it." She went up at once and took from the pile the first one that her hand rested upon, which was a letter of eleven foolscap pages, written by St. George Tucker to William Wirt, dated sometime early in 1800 . The letter showed that it was in reply to one from Mr. Wirt, telling Judge Tucker that he was about to write the life of Patrick Henry, and he desired to get his estimate of Mr. Henry as a lawyer, an orator, a statesman and a man.

Mrs. Lyons generously presented me with this letter, and in removing my effects from the city of Washington back to Lexington about 1905 the letter was lost. Parts of it, however, are supplied in Henry's life of Patrick Henry, and my own recollection of its contents is quite clear as I was constantly reading it to friends. He began his letter to Mr. Wirt by stating that he had received his letter telling him that he was about to write the life of Patrick Henry, and desired his estimate of him; quite frankly, if not bluntly, Judge Tucker expressed his regret that he had written him because he did not like Governor Henry.* When I got to this point in reading the letter I realized that my interpretation of the word "But" had been correct. He proceeded to give his reasons for his feeling towards him. That during the Revolutionary War, when Patrick Henry was governor of Virginia, he had sent for him and told him that he was expecting an invasion of Virginia by the British, and that the Virginia troops were sadly in need of arms and munitions, and asked him if he would be willing to undertake an expedition to the West Indies taking out a cargo of indigo, and bringing back arms and munitions for the Virginia troops. He agreed to do so, and was furnished with $\$ 2500$ of the State's money, to which he added $\$ 500$ of his own means, and started at once on 
the undertaking. Within three months the arms were in the hands of the Virginia troops. From memory I undertake to quote the subsequent part of the letter: "On my return I went at once to Williansburg to report to Governor Henry, and when I went into his office to sèe him, he did not even ask me to take a seat,* and I made my report to him standing, and when I had finished it, he uttered no wörd of commendation or thanks for my work, but only said, 'I think you paid too much for indigo.' I was very indignant and as I write this to you I feel the blood rushing to my head in indignation at his lack of courtesy, and I regret, therefore, that you have written me on the subject of your letter. But as you have written me I may say it had been my privilege to hear many of the accomplished orators of that day, and I had heard Governor Henry quite often, but there were several among them whom I regarded at first as superior to Governor Henry as finished orators; but it was my privilege to hear him in the Virginia Convention in old St. John's church in Richmond in 1776 , and that scene can never be effaced from my mind, and words are perfectly inadequate to describe the wonderful exhibition of power and of eloquence, which his speech on that occasion demonstrated. I believe that nothing has ever excelled it, and nothing has ever equaled it in its power and effect. When he reached that point in his speech where he said, 'We must fight! -I repeat it, we must fight! an appeal to arms and the God of Hosts is all that is left us!' his whole manner changed.

"Imagine to yourself, this sentence delivered with all the calm dignity of Cato, of Utica-imagine to yourself the Roman senate, assembled in the capitol, when it was entered by the profane Gauls, who, at first, were awed by their presence, as if they had entered an assembly of the Gods!-imagine that you heard that Cato addressing such a senate-imagine that you saw the handwriting on the wall of Belshazzar's palace-imagine you heard a voice as from heaven uttering the words: 'We must fight,' as the doom of fate, and you may have some idea of the speaker, the assembly to whom he addressed himself, and the auditory, of which I was one."

"It was on that occasion that I first felt a full impression 
of Mr. Henry's powers. In vain should I attempt to give you any idea of his speech. He was calm and collected! Touched upon the origin and progress of the dispute between Great Britain and the Colonies! The various conciliatory measures adopted by the latter, and the uniformly increasing tone of violence and arrogance on the part of the former."

So while the letter nas been lost, the last two paragraphs quoted above were taken by Mr. Wirt Henry from the letter when in his possession, and so that much of it at least has been saved. I have been greatly disturbed at its loss, and thought it worth while to preserve its contents while it was fresh in my mind.

I have recorded these facts with no idea that they would tend to dim the glory of Virginia's illustrious patriot, and unequaled orator, but rather as an illustration of the pranks of genius. Genius is not conventional, it does not follow beaten paths, it is often the child of eccentricity, and the product of inconsistencies. All who knew Governor Henry testify to his uniform courtesy and kindness of heart. Especially was this so in his public relations. The intensity of his nature, his vivid imagination as it soared through every realm of human experience to supply his illustrations, his deep abstraction when his mind was working out the great problems of liberty for his people, would naturally make him at times forgetful of the little amenities of life, and we may well therefore, ask which of the great specimens of his eloquence that fired the heart of a continent to arms, did Governor Henry have on the stocks and in his thoughts, when Judge Tucker on that eventful day unwittingly disturbed his train of thought with the dry details of indigo and the price thereof. This instance recalls one in my own experience.

Some years ago, being in London, I called upon an English barrister whom I had known in America, whose learning in the law has made his name known throughout the world. When I entered his office he looked up indifferently, arose and spoke to me. There was a distinct lack of what we call cordiality. "He did not even ask me to take a seat." In his conversation he was 
hesitating and seemed to be entirely devoid of interest in his visitor. I stayed only as long as politeness would dictate, and left not in a happy state of mind. To my surprise that afternoon a polite invitation to dine with him was received, which was accepted. When I left the dinner a few days afterwards I state unqualifiedly that he had been one of the most delightful hosts I had ever seen. In every respect he had shown the most instinctive qualities of gentility and of genuine hospitality, but when I met him in his office, he had not asked me to take a seat!

Henry St. George Tucker.

Lexington, Virginia. 